\title{
Pengaruh Penambahan Ekstrak Bawang Tiwai (Eleutherine americana Merr) pada Komposisi Kimia, Kualitas Fisik, Organoleptik dan Vitamin C Nugget Ayam Arab (Gallus turcicus)
}

\author{
A. Ismanto, D. Arsanto dan Suhardi \\ Jurusan Peternakan, Fakultas Pertanian, Universitas Mulawarman. Kampus Gunung Kelua Jl. Paser \\ Belengkong P.O. BOX 1040 Samarinda 75123 \\ E-mail:arif_fpt01@yahoo.co.id
}

\begin{abstract}
ABSTRAK
Penelitian bertujuan untuk mengetahui pengaruh penambahan ekstrak bawang tiwai (Eleutherine americana Merr) terhadap komposisi kimia, kualitas fisik, kualitas organoleptik dan kandungan vitamin $\mathrm{C}$ nugget daging ayam arab (Gallus turcicus). Penelitian terdiri dari empat perlakuan: 1) tanpa penambahan ekstrak bawang tiwai (EBT), 2) penambahan 5\% EBT, 3) penambahan $10 \%$ EBT, 4) penambahan $15 \%$ EBT. Variabel yang diamati komposisi kimia (kadar air, kadar lemak dan kadar abu), kualitas fisik ( $\mathrm{pH}$ dan susut masak) dan kualitas organoleptik (warna, rasa, keempukan dan daya terima). Data komposisi kimia dan kualitas fisik dianalisis menggunakan ANOVA, dan diuji lanjut menggunakan Least Significant Different. Data kualitas organoleptik dianalisis menggunakan Uji Sensoris Kruskal dan Wallis. Hasil penelitian menunjukkan bahwa penambahan EBT berpengaruh signifikan terhadap kadar air, kadar lemak,kadar abu dan kadar vitamin $\mathrm{C}(\mathrm{P}<0,05)$. Penambahan EBT juga berpengaruh signifikan $(\mathrm{P}<0,05)$ terhadap kualitas fisik $(\mathrm{pH}$ dan susut masak) dan semua peubah organoleptik kecuali daya terima. Hasil penelitian menunjukkan bahwa penambahan EBT sampai 15\% meningkatan kadar air, kadar lemak,kadar abu dan kadar vitamin C. Penambahan EBT sampai 15\% menurunkan kualitas fisik (pH dan susut masak). Kualitas organoleptik rasa, bau tekstur dan keempukkan meningkat tetapi kualitas oragnoleptik warna menurun dengan penambahan EBT sampai 15\% dibanding kontrol. Nugget dengan penambahan EBT sampai 15 $\%$ masih dapat diterima oleh panelis.
\end{abstract}

Kata kunci: nugget, ekstrak bawang tiwai, komposisi kimia, kualitas fisik, organoleptik dan kadar vitamin $\mathrm{C}$

\section{Effect of Addition Different Concentrations Tiwai Onion Extract (Eleutherine americana Merr) to Chemical Composition, Physical, Organoleptical Quality, and Vitamin C of Gallus turcicus Meat Nugget}

\begin{abstract}
This research was conducted to know the effect of different concentrations addition of Tiwai onion extract (Eleutherine americana Merr) on chemical composition, physical, organoleptical quality, and Vitamin C content of nugget from Gallus turcicus meat. There were four treatments in this experiment, 1) without Tiwai onion extract (TOE), 2) level of $5 \%$ TOE, 3) level of $10 \%$ TOE, 4) level of $15 \%$ TOE. The variable were observed of chemical composition (water, fat, and ash content), physical quality ( $\mathrm{pH}$ and cooking loss) and sensoric quality (colour, taste, tenderness, texture and acceptability). Chemical composition and physical quality were analysed by ANOVA, when the different between means were tested by Least Significant Difference Test. Sensory characterictic quality were analysed by hedonic test of Kruskal and Wallis. Result showed that the addition of TOE up to $15 \%$ affected significantly on water, fat, ash and vitamin $C$ content $(P<0.05)$. Addition of TOE was also affected significantly $(P<0.05)$ onpH, cooking loss and all organoleptical quality except acceptability. Result showed that the addition of TOE up to $15 \%$ increasing water, fat, ash and
\end{abstract}


vitamin C content. Addition of TOE up to $15 \%$ decreasing physical quality ( $\mathrm{pH}$ and cooking loss). Organoleptical quality taste, flavor, texture and tenderness increased but colour was decrease compare to control. Nugget by addition EBT up to $15 \%$ still acceptable for panelis.

Key words: nugget, Eleutherine americana Merr extract, chemical composition, physical quality, organoleptical quality, vitamin C content

\section{PENDAHULUAN}

Perkembangan

pemahaman mengenai senyawa fungsional dalam pangan menggerakkan kesadaran konsumen tentang kesehatan. Perkembangan pemahaman ini juga berperan membentuk tren modifikasi pangan dengan atribut tambahan berupa fungsi kesehatan (Olmedilla-Alonso et al., 2013). Komponen fungsional dalam pangan seperti protein sayuran, serat, bakteri asam laktat, dan tanaman herbal dapat ditambahkan secara langsung pada produk daging selama proses pengolahan untuk meningkatkan nilai fungsional pangan (Zhang et al., 2010).

Pangan yang mengandung antioksidan sangat dianjurkan untuk mempertahankan fungsi kekebalan dan mengurangi resiko penyakit kardiovaskular (Thomas et al., 2010). Vitamin A, C, dan E adalah beberapa contoh substansi yang bisa berperan sebagai antioksidan. Konsumen mengkonsumsi vitamin tersebut pada aras yang jauh di bawah rekomendasi yang dianjurkan (Dietary Guidelines for Americans, 2005). Penambahan substansi yang mengandung antioksidan dalam bentuk vitamin ke dalam pangan memungkinkan pangan tersebut menjadi bermanfaat untuk kesehatan dan memungkinkan juga untuk menjaga kondisi pangan tersebut tetap dalam kondisi baik.

Umbi bawang tiwai (Eleutherine americana Merr) telah digunakan sebagai pengobatan tradisonal melawan kanker payudara oleh penduduk lokal Kalimantan karena fungsinya sebagai immunostimulant, antiinflammatory, antitumor, dan proteksi jantung pada penderita kelainan jantung koroner (Upadhyay et al., 2013). Bawang tiwai (Eleutherine americana Merr) merupakan bahan yang mengandung alkaloid, saponin, dan bahan-bahan lain. Selain itu bawang tiwai mengandung vitamin $\mathrm{C}$ pada aras yang cukup tinggi. Penambahan ekstrak bawang tiwai ke dalam produk pangan yang memiliki kandungan vitamin $\mathrm{C}$ rendah dapat meningkatkan kualitas produk.

Bawang tiwai telah digunakan dalam prosesing pangan, salah satunya adalah untuk pewarna alami (Saragih et al., 2010), pengawet, antioksidan dan preservasi pangan (Suroto, 2012). Pada penelitian tersebut, ekstrak bawang tiwai digunakan sebagai pewarna alami selai kulit pisang kepok (Musa paradisiaca Linn). Penelitian dilakukan pada produk prosesing daging unggas, yaitu chicken nugget. Penelitian dimaksudkan untuk mengetahui seberapa besar pengaruh penambahan ekstrak bawang tiwai terhadap kulitas nugget (kimia, fisik, organoleptik) dan kadar antioksidan. Antioksidan yang diobservasi dalam penelitian ini adalah vitamin $\mathrm{C}$.

\section{MATERI DAN METODE}

\section{Bahan dan Alat}

Bahan utama yang digunakan dalam penelitian ini adalah $2.000 \mathrm{~g}$ daging dada ayam arab (Gallus turcicus) bagian Pectoralis superficialis dan Pectoralis profundus. Ayam arab yang digunakan adalah ayam arab betina berumur 5 bulan. Bahan tambahan yang digunakan bumbubumbu, tepung terigu, tepung roti, dan ekstrak yang berasal dari umbi bawang Tiwai (Eleutherine americana Merr) yang dipanen pada umur 4 bulan. Alat yang digunakan, yaitu: timbangan, $\mathrm{pH}$ meter, grinder, alat gravimetric, waterbath, chopper, dan seperangkat alat proksimat. 


\section{Prosedur Penelitian}

Penelitian menggunakan analisis variansi yang disusun dalam Rancangan Acak Kelompok (RAK) dengan konsentrasi ekstrak bawang tiwai yang terdiri dari 4 aras, yaitu: $0,5,10$, dan 15\%. Data dianalisis menggunakan ANOVA dan dilanjutkan dengan Uji Beda Nyata Jujur dengan $\alpha: 5 \%$ untuk perlakuan yang menunjukkan beda nyata (Steel dan Torrie, 1993).

\section{Pembuatan ekstrak bawang Tiwai (Eleutherine americana Merr)}

Umbi bawang tiwai dicuci menggunakan air destilasi, dikeringkan dalam oven pada suhu $60^{\circ} \mathrm{C}$ selama 1 malam, dan di-blender selama 5 menit untuk mendapatkan partikel yang halus. Selanjutnya diekstraksi dengan air suling dalam rasio 1 : $10(\mathrm{~b} / \mathrm{v})$ pada suhu $80{ }^{\circ} \mathrm{C}$ selama satu jam. Ekstrak disaring dengan kertas saring whatman $125 \mathrm{~mm}$ (Whatman Int. Ltd.). Bagian yang bening diambil sebagai hasil ekstraksi bawang tiwai (Nuphet dan Piyawan, 2013).

\section{Pembuatan nugget ayam arab}

Nugget yang digunakan dalam penelitian ini seberat $500 \mathrm{~g}$ dengan komposisi penyusun nugget daging $352 \mathrm{~g}$ (70,4\%), Ekstrak bawang tiwai $25 \mathrm{~g}(5 \%)$, air $18 \mathrm{~g} \mathrm{(3,6 \% ),} \mathrm{filler} 62 \mathrm{~g}(12,4 \%)$, bumbu $15 \mathrm{~g}(3 \%)$, dan es batu $7 \mathrm{~g}(1,4 \%)$. Daging dicampur dengan bumbu dan tepung. Selanjutnya dibagi menjadi 4 adonan, yaitu: adonan dengan penambahan ekstrak bawang tiwai $0,5,10$, dan $15 \%$. Persentase EBT didasarkan konsentrasi ekstrak pada $25 \mathrm{~g}$ EBT yang ditambahkan pada setiap perlakuan. Adonan nugget dikukus selama 30 menit dan didinginkan pada suhu ruang selama 10 menit. Selanjutnya adonan nugget didinginkan dalam refrigerator $\left(10{ }^{\circ} \mathrm{C}\right)$ selama 15 menit. Tahap berikutnya, nugget dipotong-potong dengan ukuran $4 \times 2 \mathrm{~cm}$, dilumuri putih telur, digulirkan pada tepung roti, dan kemudian disimpan di dalam freezer selama 24 jam. Nugget di-thawing pada suhu ruang selama 15 menit, dan dilakukan pengujian kualitas kimia, fisik dan kadar vitamin C. Selanjutnya disiapkan sampel untuk uji organoleptik melalui proses penggorengan menggunakan minyak mendidih (180-195 $\mathrm{C})$ selama kurang lebih 3 menit.

\section{Pengujian komposisi kimia dan kadar vitamin C}

Analisis komposisi kimia nugget ayam yang dilakukan adalah analisis kadar air, kadar lemak, dan kadar abu menurut metode analisis proksimat (AOAC, 1995).

Kadar vitamin C. Penentuan kadar vitamin $\mathrm{C}$ dilakukan dengan Metode Titrimetri menurut Sudarmadji et al. (2003).

\section{Pengujian kualitas fisik}

Pengukuran pH. Nilai $\mathrm{pH}$ diuji dengan menggunakan elektroda glass $\mathrm{pH}$ meter mengikuti metode yang telah dilakukan oleh Tan et al. (2007).

Susut Masak. Pengujian susut masak dilakukan menurut metode Bouton et al. (1976). Sampel dimasukkan ke dalam plastik polyethylene, selanjutnya dipanaskan dalam waterbath suhu $80^{\circ} \mathrm{C}$ selama satu jam. Berat yang hilang selama pemasakan dihitung menggunakan rumus perhitungan :

Susut masak $=\frac{\text { Berat sebelum dioven }- \text { Berat setelah dioven }}{\text { Berat sebelum dioven }} \times 100 \%$

\section{Pengujian kualitas organoleptik}

Uji organoleptik adalah suatu pengujian terhadap sifat karakteristik bahan pangan dengan menggunakan indera manusia termasuk indera penglihatan, pembau, dan perasa (Kartika et al., 1988). Pengujian organoleptik dilakukan menggunakan panelis sebanyak 15 orang yang dipilih dari kalangan terbatas kemudian dilatih (panelis semi terlatih).

Panelis berasal dari mahasiswa, berusia antara 20-25 tahun, tidak merokok, dan tidak dibedakan berdasar jenis kelamin. Skor penilaian karakteristik sensoris warna (1-5: sangat terang-sangat gelap), tekstur (15: sangat kompak-sangat tidak kompak), keempukan (sangat keras-sangat empuk), 
rasa (1-5: sangat pahit-sangat tidak pahit), bau (1-5: sangat menyengat-sangat tidak menyengat), dan daya terima (1-5: sangat bisa diterima-sangat tidak bisa diterima).

\section{HASIL DAN PEMBAHASAN}

\section{Komposisi Kimia}

Pengaruh penambahan aras ekstrak bawang tiwai terhadap komposisi kimia dan karakteristik fisik nugget ayam arab disajikan pada Tabel 1. Hasil analisis statistik menunjukkan bahwa penambahan ekstrak bawang tiwai dengan konsentrasi yang berbeda memberikan pengaruh yang signifikan terhadap komposisi kimia $(\mathrm{P}<$ 0,05).

Penambahan ekstrak bawang tiwai pada aras $0 \%$ memiliki kadar air terendah

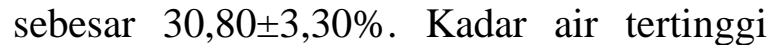
terdapat pada perlakuan penambahan ekstrak bawang tiwai aras $15 \%$ sebesar $58,80 \pm 0,60 \%$. Kadar air yang tinggi disebabkan oleh kandungan protein yang tinggi di dalam nugget akibat penambahan bawang tiwai. Bawang tiwai mempunyai kadar protein sebesar $14,46 \%$ (Suroto dan Eldha, 2007). Protein mempunyai kemampuan untuk mengikat air yang ada di dalam produk (Soeparno, 2005), sehingga semakin banyak protein di dalam suatu produk akan menyebabkan air yang terikat juga semakin tinggi.

Semua sampel nugget dalam penelitian ini memiliki kadar air dalam kisaran yang normal berdasarkan Standar Nasional Indonesia No. 01-6683-2002, yaitu: maksimum 60\% (BSN, 2002)

Penambahan konsentrasi bawang tiwai menunjukkan penambahan konsentrasi sebesar $15 \%$ memiliki kadar lemak yang paling tinggi. Hal ini dikarenakan kandungan ekstrak bawang tiwai memiliki kadar lemak relatif tinggi yaitu $1,03 \%$ (Upadhyay et al., 2013), sehingga pada nugget dengan konsentrasi penambahan $15 \%$ mendapatkan penambahan lemak dalam jumlah yang paling banyak. Semua sampel dalam penelitian memiliki kadar lemak dalam kisaran yang normal Standar Nasional Indonesia No. 01-6683-2002 bahwa kadar lemak nugget ayam maksimum sebesar $20 \%$ (BSN, 2002).

Penambahan ekstrak bawang tiwai $15 \%$ juga memiliki kadar abu paling tinggi, sehingga peningkatan kandungan mineral tertinggi tersebut karena adanya penambahan konsentrasi tertinggi dari kandungan mineral bawang tiwai. Nawawi et al. (2007) menyatakan bahwa karakteristik bawang tiwai memiliki kadar abu total 1,4\%. Sudarmadji et al. (2003) menyebutkan bahwa kadar abu dalam suatu bahan pangan adalah hasil pembakaran garam mineral.

\section{Kualitas Fisik dan Kadar Vitamin C Nugget Ayam Arab}

\section{Nilai pH}

Penambahan ekstrak bawang tiwai dengan aras yang berbeda juga memberikan pengaruh yang signifikan pada kualitas fisik ( $\mathrm{pH}$ dan susut masak) dan Vitamin $\mathrm{C}$ $(\mathrm{P}<0,05)$. Penambahan aras konsentrasi bawang tiwai menunjukkan tren penurunan $\mathrm{pH}$ dan kenaikkan kandungan vitamin $\mathrm{C}$. Perlakuan penambahan ekstrak bawang tiwai pada aras $15 \%$ memiliki nilai $\mathrm{pH}$ terendah yaitu sebesar $6,00 \pm 0,01 \%$.

Nilai $\mathrm{pH}$ tertinggi terdapat pada perlakuan penambahan ekstrak bawang tiwai aras $0 \%$ yaitu $6,20 \pm 0,06 \%$. Nilai $\mathrm{pH}$ bawang tiwai adalah sebesar 4,00 (Saragih et al., 2010). Semakin tinggi konsentrasi bawang tiwai yang ditambahkan maka nilai $\mathrm{pH}$ akan semakin rendah.

Nilai pH kemungkinan juga dipengaruhi oleh komponen alkali yang ada di dalam bawang tiwai misalnya alkaloid dan kolin (Suroto, 2012). Nilai pH yang rendah diikuti dengan kadar vitamin $\mathrm{C}$ yang tinggi, hal ini disebabkan vitamin $\mathrm{C}$ (asam askorbat) bersifat asam (Valente et al., 2011).

Hubungan antara penurunan $\mathrm{pH}$ yang diikuti dengan peningkatan kadar vitamin $\mathrm{C}$ ini sesuai dengan hasil analisis (Tabel 1). 
Tabel 1. Pengaruh pemberian aras ekstrak bawang tiwai (EBT) dengan konsentrasi 0, 5, 10, dan $15 \%$ terhadap rerata komposisi kimia, kulitas fisik dan kadar vitamin $\mathrm{C}$ nugget ayam arab

\begin{tabular}{ccccccc}
\hline \hline Aras EBT & $\begin{array}{c}\text { Kadar air } \\
(\%)\end{array}$ & $\begin{array}{c}\text { Lemak } \\
(\%)\end{array}$ & $\begin{array}{c}\text { Abu } \\
(\%)\end{array}$ & $\begin{array}{c}\text { Susut masak } \\
(\%)\end{array}$ & $\mathrm{pH}$ & Vitamin C \\
\hline $0 \%$ & $30,80^{\mathrm{c}}$ & $1,67^{\mathrm{d}}$ & $2,00^{\mathrm{d}}$ & $1,40^{\mathrm{a}}$ & $6,20^{\mathrm{a}}$ & $6,45^{\mathrm{c}}$ \\
$5 \%$ & $50,80^{\mathrm{b}}$ & $5,47^{\mathrm{c}}$ & $2,33^{\mathrm{c}}$ & $0,61^{\mathrm{b}}$ & $6,10^{\mathrm{b}}$ & $8,36^{\mathrm{b}}$ \\
$10 \%$ & $53,60^{\mathrm{b}}$ & $7,20^{\mathrm{b}}$ & $2,67^{\mathrm{b}}$ & $0,36^{\mathrm{c}}$ & $6,10^{\mathrm{b}}$ & $8,80^{\mathrm{a}}$ \\
$15 \%$ & $58,80^{\mathrm{a}}$ & $8,33^{\mathrm{a}}$ & $3,73^{\mathrm{a}}$ & $0,24^{\mathrm{c}}$ & $6,00^{\mathrm{c}}$ & $9,02^{\mathrm{a}}$ \\
\hline
\end{tabular}

${ }^{\overline{a-c}}$ Superskrip yang berbeda pada kolom yang sama menunjukan perbedaan yang nyata $(\mathrm{P}<0,05)$

Tabel 2. Pengaruh pemberian aras ekstrak bawang tiwai (EBT) dengan konsentrasi 0, 5, 10, dan $15 \%$ terhadap rerata kualitas organoleptik nugget ayam arab

\begin{tabular}{ccccccc}
\hline $\begin{array}{c}\text { Aras } \\
\text { PEBT }\end{array}$ & Warna & Rasa & Bau & Keempukan & Tekstur & $\begin{array}{c}\text { Daya } \\
\text { Terima }\end{array}$ \\
\hline $0 \%$ & $1,80^{\mathrm{c}}$ & $2,67^{\mathrm{b}}$ & $3,53^{\mathrm{a}}$ & $2,80^{\mathrm{b}}$ & $3,33^{\mathrm{a}}$ & 2,08 \\
$5 \%$ & $2,93^{\mathrm{b}}$ & $3,47^{\mathrm{a}}$ & $2,47^{\mathrm{b}}$ & $3,33^{\mathrm{a}}$ & $2,33^{\mathrm{b}}$ & 2,08 \\
$10 \%$ & $3,07^{\mathrm{b}}$ & $3,67^{\mathrm{a}}$ & $2,67^{\mathrm{b}}$ & $3,53^{\mathrm{a}}$ & $2,27^{\mathrm{b}}$ & 2,07 \\
$15 \%$ & $3,67^{\mathrm{a}}$ & $3,80^{\mathrm{a}}$ & $2,13^{\mathrm{b}}$ & $3,60^{\mathrm{a}}$ & $2,07^{\mathrm{b}}$ & 2,05 \\
\hline
\end{tabular}

${ }^{\mathrm{a}-\mathrm{c}}$ Superskrip yang berbeda pada kolom yang sama menunjukan perbedaan yang nyata $(\mathrm{P}<0,05)$

Keterangan: Skor penilaian karakteristik sensoris warna (1-5: sangat terang-sangat gelap), rasa (1-5: sangat pahit-sangat tidak pahit), bau (1-5: sangat menyengat-sangat tidak menyengat), keempukkan (15: sangat keras-sangat empuk), tekstur (1-5: sangat kompak-sangat tidak kompak) dan daya terima (15: sangat bisa diterima-sangat tidak bisa diterima).

\section{Susut masak}

Perlakuan konsentrasi bawang tiwai pada level $0 \%$ berbeda nyata $(\mathrm{P}<0,05)$ dengan perlakuan bawang tiwai level 5,10 dan $15 \%$. Perlakuan penambahan ekstrak bawang tiwai pada level $15 \%$ memiliki nilai susut masak terendah yaitu sebesar $0,24 \pm 0,02 \%$ dibanding 0 dan $5 \%$, dan susut masak tertinggi terdapat pada perlakuan penambahan ekstrak bawang tiwai aras $0 \%$ yaitu $1,40 \pm 0,20 \%$ dibanding 0 dan $5 \%$. Hal ini kemungkinan disebabkan ekstrak bawang tiwai yang ditambahkan pada nugget mengandung kadar lemak yang tinggi. Pemanasan akan menyebabkan lemak mencair, lemak tersebut akan menyelimuti produk sehingga menghalangi keluarnya air dari dalam nugget dan akibatnya susut masak menjadi lebih kecil Soeparno (2005). Lebih lanjut dijelaskan bahwa daging dengan susut masak yang lebih rendah mempunyai kualitas yang relatif lebih baik daripada daging dengan susut masak lebih besar, karena kehilangan nutrisi selama pemasakan akan lebih sedikit.

\section{Vitamin C}

Perlakuan konsentrasi bawang tiwai pada aras $0 \%$ berbeda nyata $(\mathrm{P}<0,05)$ dengan perlakuan bawang tiwai aras 5, 10 dan $15 \%$. Perlakuan penambahan ekstrak bawang tiwai pada aras $15 \%$ memiliki kadar vitamin $\mathrm{C}$ tertinggi yaitu sebesar 9,02 $\pm 0,01 \%$ dibanding 0 dan $5 \%$, danvitamin $\mathrm{C}$ terendah terdapat pada perlakuan penambahan ekstrak bawang tiwai aras $0 \%$ yaitu $6,45 \pm 0,25 \%$ dibanding 0 dan 5\%. Berdasarkan data dari Departemen Kesehatan RI (2005) bawang tiwai mengandung vitamin $\mathrm{C}$ sebesar 16,10 $\mathrm{mg} / 100 \mathrm{~g}$. Semakin tinggi penambahan konsentrasi ekstrak bawang tiwai mengakibatkan semakin tinggi kadar vitamin 
$\mathrm{C}$ pada nugget. Kandungan vitamin $\mathrm{C}$ yang meningkat mempunyai nilai tambah pada produk nugget, karena dapat meningkatkan kualitas nugget, hal ini sesuai dengan pendapat Hwang et al. (2013) merekomendasikan penambahan vitamin $\mathrm{C}$ untuk meningkatkan daya simpan dan kualitas nugget.

Selain itu peningkatan kadar vitamin $\mathrm{C}$ pada nugget juga dipengaruhi oleh Vitamin $\mathrm{C}$ itu sendiri, dimana vitamin $\mathrm{C}$ merupakan vitamin yang sangat mudah teroksidasi secara reversible menjadi asam L-dehidroaskorbat. Asam L-dehidroaskorbat secara kimia sangat labil dan dapat mengalami perubahan menjadi asam Ldiketogulat yang tidak memiliki keaktifan sebagai vitamin $\mathrm{C}$ lagi. Jadi, jika vitamin $\mathrm{C}$ pada nugget dengan penambahan ekstrak bawang tiwai teroksidasi dengan vitamin $\mathrm{C}$ dari ekstrak bawang tiwai maka menghasilkan vitamin $\mathrm{C}$ yang lebih tinggi (Winarno, 2004).

\section{Kualitas Organoleptik Nugget Daging Ayam Arab}

Pengaruh penambahan aras ekstrak bawang tiwai terhadap kualitas organoleptik nugget ayam arab disajikan pada Tabel 2 . Aras konsentrasi ekstrak bawang tiwai yang berbeda memberikan pengaruh yang signifikan pada warna, rasa, bau, keempukan, dan tekstur $(\mathrm{P}<0,05)$, tetapi tidak memberikan efek yang signifikan pada daya terima.

Hasil uji organoleptik warna, skor warna tertinggi pada perlakuan tanpa penambahan bawang tiwai yaitu sebesar 1,80 (kuning keemasan). Nilai terendah terdapat pada perlakuan $15 \%$ sebesar 3,67 (merah kecoklatan). Hasil tersebut dapat dinyatakan bahwa semakin tinggi konsentrasi bawang tiwai maka skor nilai warna nugget daging ayam arab akan semakin menurun. Hal ini disebabkan panelis tidak menyukai produk yang terkesan gelap. Warna yang didapatkan dari penambahan ekstrak bawang tiwai ini disebabkan karena adanya warna dari ekstrak bawang tiwai. Suroto dan Eldha (2007) menyatakan hasil ekstrak bawang tiwai berwarna merah marun atau merah kecoklatan. Warna merah ini dipengaruhi kandungan antosianin dalam ekstrak bawang tiwai (Winarno, 2004).

Skor hedonik rasa dan bau menunjukkan bahwa pemberian bawang tiwai dengan konsentrasi yang berbeda mempunyai pengaruh yang signifikan $(\mathrm{P}<0,05)$ terhadap kontrol. Skor rasa tertinggi terdapat pada perlakuan tanpa penambahan bawang tiwai yaitu sebesar 2,67 (gurih), dan nilai terendah terdapat pada perlakuan $15 \%$ sebesar 3,80 (pahit). Semakin tinggi konsentrasi bawang tiwai maka skor rasa semakin turun, hal ini kemungkinan disebabkan kandungan saponin dan tanin yang terdapat pada bawang tiwai tinggi, sehingga menimbulkan rasa sepat atau pahit (Suroto dan Eldha, 2007). Hal ini juga diperkuat oleh Winarno (2004) bahwa rasa sepat atau pahit suatu produk dapat disebabkan oleh adanya tanin.

Hasil uji hedonik bau, skor bau yang paling disukai adalah perlakuan dengan tanpa penambahan bawang tiwai yaitu sebesar 3,53 (tidak menyengat), sedangkan nilai terendah terdapat pada perlakuan $15 \%$ sebesar 2,13 (menyengat). Hal ini dikarenakan semakin tinggi konsentrasi bawang tiwai dalam nugget daging ayam arab, semakin banyak senyawa sumber bau yang menimbulkan aroma bawang tiwai (Saptowalyono, 2007).

Hasil analisis statistik skor organoleptik keempukan menunjukkan bahwa pemberian bawang tiwai dengan konsentrasi yang berbeda, mempunyai pengaruh yang signifikan $(\mathrm{P}<0,05)$ terhadap nugget yang dihasilkan. Hasil uji keempukan memiliki skor keempukan tertinggi pada perlakuan bawang tiwai $15 \%$ sebesar 3,60 (empuk) sedangkan nilai terendah adalah nugget tanpa penambahan bawang tiwai sebesar 2,80 (keras). Keempukan berkaitan dengan daya ikat air dan jus daging (Soeparno, 2005). Kehilangan jus daging pada nugget dengan penambahan konsentrasi bawang tiwai $15 \%$ paling 
sedikit (susut masak terendah yaitu $0,24 \pm 0,02 \%)$, sehingga nugget yang dihasilkan memiliki skor organoleptik keempukan paling baik.

Hasil analisis statistik skor organoleptik tekstur menunjukkan bahwa bahwa pemberian bawang tiwai dengan konsentrasi yang berbeda, mempunyai pengaruh yang signifikan $(\mathrm{P}<0,05)$ terhadap nugget yang dihasilkan. Hasil uji tekstur, nugget dengan penambahan bawang tiwai 15 $\%$ memiliki skor tekstur tertinggi yaitu sebesar 2,07 (kompak), sedangkan nilai terendah adalah nugget tanpa penambahan ekstrak bawang tiwai yaitu sebesar 3,33 (tidak kompak). Hal ini kemungkinan berkaitan dengan kadar lemak dalam produk. Chen (2003) menyatakan bahwa tekstur dipengaruhi oleh kadar lemak, semakin tinggi kadar lemak maka tekstur yang di hasilkan semakin kompak. Hasil pengujian kadar lemak nugget dengan penambahan ekstrak bawang tiwai sebesar $15 \%$ adalah paling tinggi yaitu $8,33 \%$ (Tabel 1), sehingga nugget dengan konsentrasi penambahan bawang tiwai $15 \%$ memiliki tekstur yang terbaik.

Hasil analisis statistik skor organleptik daya terima menunjukkan bahwa pemberian ekstrak bawang tiwai dengan konsentrasi yang berbeda, tidak memberikan pengaruh yang signifikan $(\mathrm{P}<0,05)$ terhadap daya terima nugget yang dihasilkan. Hasil uji daya terima memiliki skor rata-rata yaitu 2,07 (bisa diterima). Hasil ini menunjukkan bahwa penambahan aras bawang tiwai sampai dengan $15 \%$ tidak memengaruhi penerimaan konsumen terhadap nugget yang dihasilkan. Penelitian lain yang dilakukan oleh Banerjee et al. (2012) menggunakan bahan tambahan yang berasal dari tanaman berupa ekstrak serbuk brokoli pada aras tertinggi (2\%) juga tidak mempengaruhi daya terima nugget yang dihasilkan.

\section{SIMPULAN}

Penambahan ekstrak bawang tiwai sampai dengan konsentrasi $15 \%$ dapat meningkatkan kadar air, kadar lemak kadar abu dan vitamin $\mathrm{C}$ pada nugget ayam arab. Penambahan ekstrak bawang tiwai sampai dengan konsentrasi $15 \%$ dapat menurunkan nilai $\mathrm{pH}$ dan susut masak pada nugget ayam Arab. Penambahan ekstrak bawang tiwai sampai dengan konsentrasi $15 \%$ meningkatkan kualitas organoleptik rasa, bau, keempukan, dan tekstur, tetapi menurunkan kualitas organoleptik warna dan tidak memengaruhi daya terima nugget ayam arab dibandingkan kontrol.

\section{DAFTAR PUSTAKA}

AOAC. 1995. Offical Methods of Analysis. $16^{\text {th }}$ ed. AOAC Int., Washington D.C.

Badan Standarisasi Nasional. 2002. Standar Nasional Indonesia. 01-6683. Nugget Ayam. Badan Standarisasi Nasional, Jakarta.

Banerjee, R., A.K. Verma, A. K. Das, V. Rajkumar, A.A. Shewalkar and H.P. Narkhede. 2012. Antioxidant effects of broccoli powder extract in goat meat nuggets. Journal of Meat Science. 91(2): 179-184.

Bouton, P.E. and P.V. Harris. 1976. The Efect of some post-slaughter treatments upon the mechanical properties of bovine and ovine muscle. Journal of Food Science. 37: 539-542.

Chen, Y.C. and B.H. Chen. 2003. Determination of polycyclic aromatic hydrocarbons in fumes from fried chicken legs. Journal of Agricultral Food Chemistry. 51(14): 4162-4167.

Deman, J.M. 1989. Kimia Makanan. Cetakan Ke-2. ITB. Bandung.

Departemen Kesehatan RI. 2005. Materia Medika Indonesia. Jilid VI. Dirjen Pengawasan Obat dan Makanan. Jakarta.

Dietary Guidelines for Americans. 2005. U.S Departement of Helath and Human Services, and U.S. Departement of Agriculture. http://www.health.gov/dietrayguidelines/dga2005/document/. Diakses tanggal 25 Februari 2014.

Hwang, K., Y. Choi, S. Choi, H. Kim, J. Choi, M. Lee, and C. Kim. 2013. Antioxidant action of ganghwayakssuk (Artemisia princeps Pamp.) in combination with ascorbic acid to increase the shelf life in 
raw and deep fried chicken nuggets Journal of Meat Science. 95(3):593-602.

Kartika B., P. Hastuti dan W. Supartomo. 1998. Pedoman Uji Inderawi Bahan Pangan. Pusat Antar Universitas Pangan dan Gizi Universitas Gadjah Mada. Yogyakarta.

Luthana, Y.K. 2008. Yoghurt.www. Youghurt« ytis'sfoodentertaining.htm. Diakses tanggal 25 Desember 2013.

Nawawi, I., R. Winasih dan A. Anggi. 2007. Isolasi dan Identifikasi Senyawa Kuinon dari Simplisia Umbi Bawang Sabrang (Eleutherine Americana Merr.). Sekolah Tinggi Farmasi Bandung, Bandung.

Nuphet, A. \& Piyawan, S. , 2013. Anaerobe Eleutherine Americana As A Growth Promotor for Infant Intestinal Microbiota. Anaerobe. 20: 14-19.

Olmedilla-Alonso, B., F. Jiménez-Colmenero, and F.J. Sánchez-Muniz. 2013. Development and assessment of healthy properties of meat and meat products designed as functional foods. Journal of Meat science. 95(4):919-30.

Saptowalyono, C.A. 2007. Bawang Dayak, Tanaman Obat Kanker yang Belum Tergarap. www.kompas.com. Diakses tanggal 15 September 2013.

Saragih, B., I. Kayati, dan D. Sumarna. 2010. Pengaruh Pewarna Ekstrak Cair Alami Bawang Tiwai (Eleutherine americana Merr.) terhadap Mutu Selai Kulit Pisang Kepok (Musa paradisiaca Linn.). Jurnal Teknologi Pertanian Universitas Mulawarman. 6(2): 55-59.

Setyowati, M.T. 2002. Sifat Fisik, Kimia dan Palatabilitas Nugget Kelinci, Sapi, Ayam yang Menggunakan Berbagai Tingkat Konsentrasi Tepung Maizena. Skripsi. Jurusan Ilmu Produksi Ternak. Fakultas Peternakan. Institut Pertanian Bogor. Bogor.

Soeparno. 2005. Ilmu dan Teknologi Daging. Gadjah Mada University Press. Yogyakarta.

Steel, R.G.D. and J.H. Torrie. 1993. Prinsip dan Prosedur Statistika Suatu Pendekatan
Biometrik. Edisi kedua. Margie Group. Jakarta

Sudarmadji, S., B. Haryono dan Suhardi. 2003. Prosedur untuk Uji Analisis Makanan dan Pertanian. Liberty. Yogyakarta.

Suroto., H. S. 2012. Bawang Tiwai (Eleutherine Americana Merr) sebagai pengawet, antioksidan, dan pewarna untuk pangan. Jurnal Riset Teknologi Industri. pp. 188196.

Suroto., H.S dan S. Eldha. 2007. Analisa Kandungan Kimia dan Pemanfaatan Bawang Tiwai (Eleutherine Americana Merr) untuk Bahan Baku Industri. Jurnal Riset Teknologi Industri. 1(2): 22-27.

Tan F.J., F.Y. Liao, Y.J. Jhan and D.C. Liu. 2007. Effect of replacing pork backfat with yams (Dioscoreaalata) on quality characteristics of Chinese sausage. Journal of Food Engineering. 79: 858863.

Thomas, R.H., M.A. Bernards, E.E. Drake and C.G. Guglielmo. 2010. Changes in the antioxidant activities of seven herb and spice based marinating sauces after cooking. Journal of Food Composition and Analysis. 23(3):244-252.

Upadhyay, A., P. Chattopadhyay, D. Goyary and P. Mitra. 2013. Eleutherine indica $L$. accelerates in vivo cutaneous wound healing by stimulating Smad-mediated collagen production. Journal of Ethnopharmacology. 146(2) : 490-494.

Valente A., G.T. Albuquerque, A. SanchesSilva, and H.S Costa. 2011. Ascorbic acid content in exotic fruits: A contribution to produce quality data for food composition databases. Food Research International. 44(2011): 22372242.

Winarno, F.G. 2004. Pangan Gizi, Teknologi dan Konsumen. Gramedia Pustaka Utama. Jakarta.

Zhang, W., S. Xiao, H. Samarraweera, E.J. Lee and D.U. Ahn. 2010. Improving functional value of meat products. Journal of Meat Science. 86(1): 15-31. 